\title{
Processing Effects on Physicochemical and Proximate Composition of Finger Millet (Eleusine coracana)
}

\section{AISONI Japhet Erasmus', YUSHA'U Muhammad², OROLE Olukayode Olugbenga*3}

\author{
${ }^{1}$ Elbe Pharma Nigeria Limited, Ajao Estate, Lagos, Nigeria \\ ${ }^{2}$ Department of Microbiology, Faculty of Life Science, Bayero University Kano, Nigeria \\ ${ }^{3}$ Department of Microbiology, Federal University Lafia, Nassarawa State, Nigeria.
}

\begin{tabular}{|c|c|}
\hline ARTICLE INFO & ABSTRACT \\
\hline $\begin{array}{l}\text { Article No.: } 032018048 \\
\text { Type: Research } \\
\text { DOI: } 10.15580 / G J B S .2018 .2 .032018048\end{array}$ & $\begin{array}{l}\text { African millet is a cereal crop with tiny seed. The study was aimed at } \\
\text { determining the effect of processing methods on the proximate, } \\
\text { phytochemical, and mineral composition of finger millets. Grains were } \\
\text { collected, roasted and another portion fermented, after which }\end{array}$ \\
\hline $\begin{array}{l}\text { Submitted: } 20 / 03 / 2018 \\
\text { Accepted: } 27 / 03 / 2018 \\
\text { Published: } 31 / 03 / 2018 \\
\end{array}$ & $\begin{array}{l}\text { showed that terpenoids, tannins, steroids, and saponin were present in } \\
\text { fermented millet, while only alkaloids, terpenoids, and tannin were the only } \\
\text { phytochemicals present in roasted millet. Bulk density of fermented millet was } \\
1158 \pm 16.51 \mathrm{~kg} / \mathrm{m}^{3} \text { and significantly different from roasted and unprocessed }\end{array}$ \\
\hline $\begin{array}{l}{ }^{*} \text { Corresponding Author } \\
\text { Japhet Erasmus AISONI } \\
\text { E-mail: orolekayode@ gmail.com } \\
\text { Phone: +2348100427374 }\end{array}$ & $\begin{array}{l}\text { Foaming Capacity in fermented millet were } 26.40 \% \text { and } 1.96 \% \text { respectively } \\
\text { and significantly different from values obtained in roasted and unprocessed } \\
\text { millet that both had } 31.80 \% \text { (DPPH activity) and (5.88 \%) foaming capacity. } \\
\text { Fermented millet had higher carbohydrate }(78.46 \%) \text {, crude fibre }(8.48 \%) \text {, and } \\
\text { energy }(327.96 \mathrm{Kcal} / 100 \mathrm{~g}) \text {, while roasted millet had higher crude protein }(6.53\end{array}$ \\
\hline $\begin{array}{l}\text { Keywords: Cereals, Energy, } \\
\text { Metabolites, Minerals, Processing }\end{array}$ & $\begin{array}{l}\text { unprocessed millets }(18.1 \%) \text { and whose value was higher than those of the } \\
\text { processed millets. Roasted millet recorded highest values for phosphorus } \\
(0.35 \%) \text {, potassium }(0.44 \%) \text {, magnesium }(0.13 \%) \text {, zinc }(25.5 \%) \text {, and iron }(74.9 \\
\%) \text {. Processing of millets helped release more nutrients and metabolites into } \\
\text { the food products, though fermented millet would be recommended as an } \\
\text { energy laden food source, rich in various phytochemicals of health benefitting } \\
\text { nature. }\end{array}$ \\
\hline
\end{tabular}
nature. 


\section{INTRODUCTION}

African finger millet (Eleucine coracana) is an annual crop belonging to the family Poaceae (Gramineae) which is grown in the arid areas of Africa and Asia. It is a cereal crop with small seeded grain but not a true caryopsis. Its pericarp (glumes) is not fused with the testa, thus the pericarp can easily be removed by rubbing or soaking in water, and other times by threshing (McDonough, et al., 1986). It possesses a white endosperm and the kernel can be spherical, globular, or oval, in shape with diameter between 1 to $1.8 \mathrm{~mm}$. Finger millet is consumed as food and feed in addition to its current usage as forage as a result of its potential benefits to give higher sustaining power, lower glycaemic response (Chethan and Melleshi, 2007).

To improve digestibility, palatability and shelf life, the cereal is subjected to different processing method and condition such as milling, boiling, roasting, and germination. The millet is used as whole flour mostly for traditional food preparation and can be consumed raw after soaking and sprouting in form of salads. Popped, malted, and fermented products (such as noodles, biscuit, miffins, vermicelli, pasta, halwa, bread, papad (Krishnan et al., 2011; Gull et al., 2015). It is known as the poor man's food because of its long sustenance as it can be stored safely for many years without infestation by insects and pests. This property makes it a very necessary famine reserve food. It is a good source of Magnesium, Manganese and phosphorus, and has been reported to have antidiabetic, antimicrobial, cataractogenetic properties which results from the presence of compounds it contains (Chethan et al., 2008; Xu et al., 2011; Banerjee et al., 2012; Chaturvedi et al., 2008).

Bioavailability of some nutrients in food supplements is limited by the presence of antinutrients such as tannins, phytates, oxalates, cyanides and saponins (Gibbs-Russell et al., 1989); and processing methods such as boiling, soaking, roasting, and fermenting reduces the anti-nutrient content of such food thus, enhancing biological availability of the nutrients.

The challenge of food scarcity and protection, high cost of antimicrobials, and the need to source for readily available and cheap sources of antimicrobials necessitated this study. The study aims to ascertain the effect of processing methods on the proximate, phytochemical, and mineral composition of finger millet varieties found in Kano State, Nigeria.

\section{MATERIALS AND METHODS}

\section{a) Procurement of finger millet}

Commercially available finger millet was purchased from the Kano State Central Market and was identified at the Herbarium unit of the Department of Biological Sciences, Ahmadu Bello University, Zaria with a voucher No 24356.

\section{b) Processing of finger millet}

\section{i) Roasting}

The finger millet (Eleusine coracana) is sorted by hand picking then washed to remove foreign materials after which the grains were rinsed and allowed to dry. After drying, the grains were roasted for $10-15 \mathrm{~min}$ (in an open pan using firewood)

ii) Fermentation: Fermentation was done by soaking the seed in clean water and covering with a sack for 24 $\mathrm{h}$ and then sun-dried.

\section{c) Physicochemical Properties}

i) Bulk density: Bulk density was carried out according to the modified methods of Mariotti et al., (2006).

\section{ii) True density}

The true density $\left(\mathrm{kg} / \mathrm{m}^{3}\right)$ was determined by the liquid displacement method using a top loading balance. A total of $100 \mathrm{~g}$ of grains were immersed in graduated beaker containing distilled water. The amount of water displacement was recorded according to the methods of Karababa and Coskuner (2013).

$\mathrm{P}_{\mathrm{t}}=\frac{30 g}{V 2-V 1}$

Where: $\mathrm{Pt}=$ true density, $\mathrm{V}_{1}=$ initial volume and $\mathrm{V}_{2}=$ final volume.

\section{iii) Porosity}

It was calculated using Equation from the true density and bulk density using method of Varnamkhasti et al. (2008).

\section{iv) Water absorption capacity}

One gram finger millet flour was transferred into weighing $50 \mathrm{~mL}$ centrifuge tubes in triplicate to which $10 \mathrm{~mL}$ distilled water was added, stirred and incubated in water bath at $30{ }^{\circ} \mathrm{C}$ for $30 \mathrm{~min}$. The centrifuge tubes were centrifuged at $3000 \mathrm{rpm}$ for $15 \mathrm{~min}$ using a Model T-8BL Laby TM centrifuge (Laboratory Instruments, Ambala Cantt India). The supernatants were discarded and the residues weighed. Two different weights of the centrifuge tubes gave water absorbance.

\section{v) Determination of dispersibility}

This was carried out using the methods of Olapade et al. (2014). A total of $10 \mathrm{~g}$ of the flour sample was weighed into $100 \mathrm{~mL}$ measuring cylinder and distilled water was added. The set up was stirred vigorously and allowed to stand for $3 \mathrm{~h}$. The volume of settled particle was recorded and subtracted from 100.

Percentage Dispersibility $=100-$ volume of settled particles 


\section{d) Proximate Composition}

Estimations were made of nitrogen (as an index of crude protein), water, fat, ash and crude fibre. When the total was subtracted from $100 \%$ the difference was termed carbohydrate by difference. Determination of the moisture content, ash and crude fat followed the method of AOAC (2005). Crude fibre determination was done following the method of Pearson (1981). Estimation of nitrogen content was by the Kjeldahl method multiplied by 6.25 , the nitrogen - protein factor to convert to crude protein.

\section{i) Moisture Content}

The moisture content was determined using procedure described by AOAC (2005). The moisture content of each samples were determined by weighing $5 \mathrm{~g}$ of the sample into aluminium moisture can. The sample was then dried to constant weight at $105^{\circ} \mathrm{C}$.

$$
\frac{\text { weight of can }- \text { weight of empty can }}{\text { weight of sample }} \times 100
$$

\section{ii) Crude Protein}

Crude protein content was measured following the procedure below: Two (2) g of sample was weighed and place in $600 \mathrm{~mL}$ Philip's conical flask, after which $1 \mathrm{~g}$ of pure scale pepsin dissolved in $490 \mathrm{~mL}$ distilled water and was added to sample. Ten (10) millilitres $25 \% \mathrm{HCl}$ (by weight) was added and place in a beaker and incubated at $38{ }^{\circ} \mathrm{C}$. After $24 \mathrm{~h}, 10 \mathrm{~mL} \mathrm{HCl}$ was further added, stirred well and returned to the incubator. After another $24 \mathrm{~h}$ the sample was filtered and washed until free from acid. The filter paper and residue were transferred to Kjeldahl flask, and nitrogen content determined using the formula below:

Percentage digestibility crude protein $=$ total crude protein - \% crude protein in filter paper residue.

\section{iii) Ash Content}

Two grams of samples was weighed in well incinerated crucibles and then ashed in a muffle furnace at $600{ }^{\circ} \mathrm{C}$ for $3 \mathrm{~h}$. The ash content was calculated as:

$\frac{\text { weight of crucible }+ \text { ash }- \text { weight of empty crucible }}{\text { weight of sample }}$

\section{iv) Crude Fibre}

Two grams of the sample was transferred into $1 \mathrm{~L}$ conical flask. One hundred millimetres of sulphuric acid $(0.255 \mathrm{~mol} / \mathrm{L})$ it was heated to boiling and then introduced into the conical flask containing the sample. The contents were then boiled for $30 \mathrm{~min}$, ensuring that the level of the acid was maintained by the addition of distilled water. After 30 min, the contents were then filtered through a muslin cloth held in a funnel. The residue was rinsed thoroughly until its washing was no longer acidic to litmus. The residue was then transferred into a conical flask. One hundred millilitres of sodium hydroxide $(0.313 \mathrm{~mol} / \mathrm{L})$ was then brought to boil and then introduced into the conical flask containing the sample. The contents were then boiled for $30 \mathrm{~min}$, ensuring that the level of the acid was maintained by the addition of distilled water. After $30 \mathrm{~min}$, the contents were filtered through a muslin cloth held in the funnel. The residue was rinsed thoroughly until its washing was no longer alkali. The residue was then introduced into an already dried crucible and ashed at $600^{\circ} \mathrm{C} \pm 200^{\circ} \mathrm{C}$.

$$
\frac{\text { final weight of crucible }- \text { initial weight of crucible }}{\text { weight of sample }}
$$

\section{e) Mineral Content}

Mineral analysis was carried out on samples digested with hydrochloric acid. Total iron (AOAC - 944.02) were analysed by colorimetric method using a bipyridyyl method (AOAC 2005). Total phosphorous was analysed colorimetrically using methods of Taussky and Shorr, (1953), while the total calcium was analysed using method of Raghuramulu, (1983).

\section{f) Statistical Analysis}

Data was analysed by (Analysis of Variance) ANOVA using SPSS 20.0 software. Values were calculated per $100 \mathrm{~g}$ of flour. All analysis was carried in 3 replicates. The results are presented as means \pm SD. The means separated using turkey's test. Level of significance was set at $P \leq 0.05$. Correlation coefficients between mineral and anti-nutrient content as well as between \% tannins and dietary fibre fractions of finger millet was determined.

\section{RESULTS}

\section{a) Phytochemical constituents of processed finger millet}

Based on the type of processing, terpenoids and tannins were the only constituent present in the millet after the two treatment methods (Table 1). Alkaloids was not found in fermented millet, while flavonoids, steroids, and saponin were absent in roasted millet. 
Table 1: Phytochemical constituents of fermented and roasted finger millet.

Type of phytochemical $\quad$ Fermented millet Roasted millet

\begin{tabular}{ccc}
\hline Alkaloids & - & + \\
Flavonoids & + & - \\
Terpenoids & + & + \\
Steroids & + & - \\
Tannins & + & + \\
Saponins & + & - \\
\hline
\end{tabular}

b) Effects of processing on the were significantly different from each other. Foam physicochemical parameters of finger stability and foaming capacity recorded no significant millet variation in values between the treatment methods as shown in Table 2, but the foaming capacity value of

Bulk density of fermented millet recorded the highest value of $1158 \mathrm{a} \pm 16.51 \mathrm{~kg} / \mathrm{m}^{3}$, while roasted millet obtained $993.6 \pm 11.44 \mathrm{~kg} / \mathrm{m}^{3}$ (Table 2). The values $5.88 \%$ obtained for unprocessed millet was significantly different from values obtained for the processed millets.

Table 2: Physicochemical properties of processed and unprocessed finger millets

\begin{tabular}{cccc}
\hline Parameter & Fermented millet & Roasted millet & Unprocessed millet \\
\hline Bulk density $\left(\mathbf{k g} / \mathbf{m}^{3}\right)$ & $1158^{\mathrm{a}} \pm 16.51$ & $993.6^{\mathrm{c}} \pm 11.44$ & $1146.80^{\mathrm{b}} \pm 16.04$ \\
True density $\left(\mathbf{k g} / \mathbf{m}^{3}\right)$ & $1613.4^{\mathrm{a}} \pm 48.02$ & $1515.6^{\mathrm{b}} \pm 34.88$ & $1515.8^{\mathrm{b}} \pm 35.33$ \\
Porosity $(\%)$ & $28.25^{\mathrm{b}} \pm 2.47$ & $32.41^{\mathrm{a}} \pm 5.40$ & $24.31^{\mathrm{c}} \pm 2.10$ \\
Dispersibility (\%) & $92.03^{\mathrm{a}} \pm 0.38$ & $84.73^{\mathrm{c}} \pm 0.64$ & $87.37^{\mathrm{b}} \pm 0.15$ \\
DPPH Activity (\%) & $26.40 \% \%^{\mathrm{b}}$ & $31.80 \%^{\mathrm{a}}$ & $31.80 \%^{\mathrm{a}}$ \\
FC (\%) & $1.96 \pm 0.00^{\mathrm{b}}$ & $1.96 \pm 0.00^{\mathrm{b}}$ & $5.88 \pm 0.00^{\mathrm{a}}$ \\
FS (ml) & $0.97 \pm 0.01^{\mathrm{a}}$ & $0.98 \pm 0.00^{\mathrm{a}}$ & $0.98 \pm 0.00^{\mathrm{a}}$ \\
\hline
\end{tabular}

Key: FC - Foaming Capacity; FS - Foam Stability

\section{c) Proximate composition of processed finger millet}

As shown in Table 3, proximate compositional values after the different treatments were administered showed that crude protein obtained $6.46 \%$ in fermented grains, while the value was $6.53 \%$ in roasted millet; carbohydrate had $78.46 \%$ and $77.29 \%$ in fermented and roasted millets respectively. Energy content showed that fermented millet would give $327.96 \mathrm{Kcal} / 100 \mathrm{~g}$ higher than $323.07 \mathrm{Kcal} / 100 \mathrm{~g}$ found in roasted millet.

Table 3: Proximate composition of processed finger millets

\begin{tabular}{ccc}
\hline Parameter & Fermented millet & Roasted millet \\
\hline Crude fat (\%) & 2.23 & 2.18 \\
Crude protein (\%) & 6.46 & 6.53 \\
Total ash (\%) & 2.84 & 2.76 \\
Carbohydrates (\%) & 78.46 & 77.29 \\
Crude fibre (\%) & 8.48 & 6.53 \\
Moisture (\%) & 9.91 & 11.25 \\
Energy (Kcal/100 g) & 327.96 & 323.07 \\
\hline
\end{tabular}

\section{d) Mineral composition of differently treated finger millet}

Fermentation of millet led to reduced values of Magnesium, Manganese, and Zinc as shown in Table
4. Calcium, phosphorus, potassium, and iron contents increased in fermented millet from 0.01 to $0.33 \%, 0.15$ to $0.24 \%, 0.21$ to $0.43 \%$, and 33.1 to $46.0 \%$ respectively. 
Table 4: Processing effect on the mineral constituent of finger millet

\begin{tabular}{|c|c|c|c|c|c|c|c|c|}
\hline \multirow{2}{*}{$\begin{array}{l}\text { Processing } \\
\text { method }\end{array}$} & $\mathrm{Ca}$ & $\mathbf{P}$ & $\mathrm{K}$ & $\mathrm{Na}$ & $\mathbf{M g}$ & $\mathrm{Fe}$ & Mn & $\mathbf{Z n}$ \\
\hline & \multicolumn{8}{|c|}{ Percentage (\%) } \\
\hline $\begin{array}{c}\text { Fermented } \\
\text { millet }\end{array}$ & 0.33 & 0.24 & 0.43 & 0.02 & 0.11 & 46.0 & 7.5 & 15.0 \\
\hline $\begin{array}{l}\text { Roasted } \\
\text { millet }\end{array}$ & 0.01 & 0.35 & 0.44 & 0.01 & 0.13 & 74.9 & 18.0 & 25.5 \\
\hline $\begin{array}{l}\text { Unprocessed } \\
\text { millet }\end{array}$ & 0.01 & 0.15 & 0.21 & 0.01 & 0.12 & 33.1 & 18.1 & 18.1 \\
\hline
\end{tabular}

\section{DISCUSSION}

Absence of saponin in roasted finger millet might be attributed to the processing method adopted in the preparation. Roasting of cereals, pulses and oilseeds which is usually by dry frying had been reported to remove from processed food anti-nutritional or toxic compounds such as gioterogenic agents, cyanogenic glycosides, alkaloids and saponins and increase storage life of such food product (Gopaldas et al., 1982; Huffman and Martin, 1994). Venkateswaran and Vijayalakshmi (2010) reported that fermented finger millet showed reduction in phytic acid and tannin contents by $88.8 \%$ and $90.1 \%$, respectively, with an increase of $61.5 \%$ minerals, reducing sugars and soluble proteins.

Phytate, an anti-nutrient stores elemental phosphorous and myoinositol; and forms crystals which are excreted in urine when it combines with divalent metallic ions like Calcium and Iron (Adesuyi et al., 2012).

The absence of flavonoids and steroid could be predicated on the roasting method employed as the fermented finger millet showed these metabolites were in the millet

Polypheneols are a large and diverse class of compounds, many of which occur naturally in a range of foods plants phenolics (hydroxy benzenes) especially polyphenols (containing two or more phenolic groups) which are ubiquitous in plants foods consumed by human and animals and one of the widest groups of a dietary supplements marketed worldwide (Ferguson, 2001). The main polyphenols in cereals are phenolic acids and tannins, while flavonoids are present in small quantities (Rao and Muralikri Shna, 2002). Although these compounds play no known direct role in nutrition, many of them have antioxidant properties which aids proper functioning of body cells. Antioxidants respond to death resulting from oxidative stress on cells and adjoining tissues integrity by scavenging reactive free radicals capable which causes cell death and tissue damage which inadvertently result in cancer, emphysema, cirrhosis, atherosclerosis, and arthritis (Shahidi and Wanasundara, 1992).

Other activities of the metabolites include antiestrogenic, anti-carcinogenic and anti- inflammatory, antiviral effects and platelet aggregation inhibitory activities that might potentially be beneficial in preventing or minimizing the incidence of diseases (Ferguson, 2001). Millet grains are rich in phenolic acids, tannins, and phytate that act as "antinutrients" (Thompson, 1993). Antinutrients reduce the risk of colon and breast cancer in animals (Graf and Eaton, 1990). Terpenoids has been reported to confer antioxidant, antimicrobial, antifungal, antiviral, antihyperglycemic, antiinflammatory, and antiparasitic activities. Phenols and flavonoids in Phenolic compounds are antimicrobial in nature especially against Gram-positive bacteria where result is dependent on concentration (Tiwari et al., 2009).

The highest mean result for 1000 sample weight was obtained from fermentation, $775 \pm 5.27 \mathrm{~g}$ and the lowest mean result for 1000 sample weight was $496.8 \pm 5.00 \mathrm{~g}$ from unprocessed (data not shown). Fermentation was significantly different ( $p<$ $0.05)$ on 1000 sample weight as compared to other samples. The results agreed with the findings of Balasubramanian and Viswanathan (2010) who obtained $185.8 \mathrm{~kg}$ at moisture content of 11.1 to $25 \%$. Values of bulk density obtained with fermentation treatment obtaining the highest bulk density and unprocessed grain with the lowest bulk density were in line with the report of Zewdu and Solomon (2007) who got 696 to $840 \mathrm{~kg} / \mathrm{m}^{3}$ for millet at a moisture content ranging from 5.6 to $29.60 \%$.

Fermented millet had the highest $(p<0.05)$ true density, followed by roasting, and unprocessed respectively. These results were in line with the findings by Vanrnamkhasti et al. (2008) for rough rice, where the mean true density ranged from 1193.38 to $1269.10 \mathrm{~kg} / \mathrm{m}^{3}$, respectively. Similar results were obtained by Balasubramanian and Viswanathan (2010) at a moisture content of 11.1 to $25 \%$, and by Jain and Bal (1997) who obtained 1578 to $1623 \mathrm{~kg} / \mathrm{m}^{3}$. Zewdu and Solomon (2007) also reported similar results of 1207 to $1361 \mathrm{~kg} / \mathrm{m}^{3}$ for millet grain at a moisture content of 5.6 to $29.6 \%$. The mean porosity results for fermented millet was the hughest, while roasted millet had the least. These results agreed with Sangamithra et al. (2016) who got 51.30 to $55.83 \%$ at a moisture content of 8.7 to $21.7 \%$ for maize, Al-Mahasnesh and Rababah (2007) ranging from 45.61 to $46.66 \%$ for green wheat, and Zewdu and Solomon (2007) with 38.31 to $42.32 \%$ for millet at a moisture content of 5.6 to $29.0 \%$.

Adebowale et al. (2012) and Markowski, et al. (2013) reported that millet have $59.62 \%$ aspect ratio at moisture content of $10 \%$ and $47.4 \%$ at a moisture content of $9.95 \%$ respectively which disagreed with our findings. Our result was in line with the findings of Baryeh (2002) of 78.30 to $80.30 \%$ at a moisture content of 5.00 to $22.5 \%$.

The results for bulk density of grains were similar to those reported by Jain and Bal (1997) who studied 3 PM cultivars ranging from 830.0 to 866.1 
$\mathrm{kg} / \mathrm{m} 3$. Goswami et al., (2015) also reported a bulk density ranging from 684.99 to $777.50 \mathrm{~kg} / \mathrm{m} 3$ on FM grains. Balasubramanian and Viswanathan (2010) obtained the same results ranging from 477.1 to 868.1 $\mathrm{kg} / \mathrm{m} 3$ at a moisture content of 11.1 to $25 \%$. Fermentation was significantly higher $(p<0.05)$ as compared to other samples. Bulk density is an essential factor that determines the grade and test weight of the grains during drying, storage.

Kamath and Belavady (1980) 3.6\% crude fibre in finger millet, while Joshi and Katoch (1990) reported $3.7 \%$ crude fibre in finger millet though the two report disagreed with findings in our study that reported high values for the two processing methods compared. Millets possesses hypoglycemic effect which is attributed to the high fibre content in it. The health benefits associated with high fibre foods are delayed nutrient absorption, increased fecal bulk, lowering of blood lipids, prevention of colon cancer, barriers of digestion, mobility of intestinal contents, increased faecal transit time and fermentability characteristics (Palasamy et al., 2011).

While sodium and magnesium did not show any significant difference resulting from the processing method employed, fermentation of millet led to reduced Manganese and Zinc content, while it increased the content of calcium, phosphorus, potassium, and iron. Roasting on the other hand increased potassium, phosphorus and zinc contents. Research have shown that Magnesium is associated with reduced risk of heart attack, phosphorus is important for the development of the body tissues and energy metabolism. It is also rich in phytochemicals including phytic acid which is believed to lower cholesterol level and phytate, which is associated with reduced risk of cancer.

\section{CONCLUSION}

Finger millet from the report of this study has considerable amount crude fat, crude protein, carbohydrates, moisture and energy which could be used as food supplement especially among the poor population. Roasting and fermenting the grain did not show any significant difference in value of the proximate and mineral composition and so, the study recommends either of the method to improve the shelflife of the product after processing.

\section{REFERENCES}

Adebowale AA, Fetuga GO, Apata CB and Sannai LO (2012). Effect of variety and initial moisture content on physical properties of improved millet grains. Nigerian Food Journal, 30(1): 5-10.

Adesuyi AO, Elumm IK, Adaramola FB and Nwokocha AGM (1992). Nutritional and phytochemical screening of Garcinia kola. advan. J Food Sci Tech., 4(1): 9-14.

Al-Mahasnesh MA and Rababah TM (2007). Effect of moisture content on some physicalproperties of green wheat. Journal of Food Engineering, 79: 1467-1473.

AOAC (2005). Official methods of analysis (18th Ed), Washington DC, Association of Official Analytical Chemists.

Balasubramanian S and Viswanathan R (2010). Influence of moisture content on physical properties of minor millets. Journal of Food Science, 47(3): 279-284.

Banerjee S, Sanjay K, Chethan S and Malleshi N (2012). Finger millet (Eleusine coracana) polyphenols: Investigation of their antioxidant capacity and antimicrobial activity. African Journal of Food Science, 6(13): 362-374.

Baryeh EA (2002). Physical properties of millets. Journal of Food Engineering, 51: 39-46.

Chaturvedi P, Singh AP, Chakraborty S, Chauhan SC, Bafna S, Meza JL, Singh PK, Hollingsworth MA, Mehta PP and Batra SK (2008). MUC4 mucin interacts with and stabilizes the HER2 oncoprotein in human pancreatic cancer cells. Cancer Res, 68: 2065-2070.

Chethan S and Malleshi NG (2007). Finger millet polyphenols: optimization of extraction and the effect of pH on their stability. Food Chem., 105: 862-870.

Chethan S, Sreerama YN and Malleshi NG (2008). Mode of inhibition of finger millet malt amylases by the millet phenolics compounds. Food Technology, 2 (7): 582-592.

Ferguson LR (2001). Role of plant polyphenols in genomic stability. Mutat Res., 475: 89-111.

Gibbs-Russell P and Deosthale YG (1989). In vitro availability of iron and zinc in white and coloured ragi (Eleusine coracana): role of tannin and phytate. Plant Foods Human Nutrition, 38: 35-41.

Gopaldas T, Inamdar F and Patel J (1982). Malted versus roasted, young child mixes: viscosity, storage and acceptability trails. Indian J. Nutr. Dietet., 19: 327-336.

Goswami D, Manikantan MR, Gupta RK and Vishwakarma RK (2015). Moisture dependent selected postharvest engineering properties of ragi (Eleusine coracana) grown in Northern Hills of India. Journal of Postharvest Technology, 3(3): 082-088.

Graf E and Eaton JW (1990). Antioxidant functions of phytic acid. Free Radical Biology and Medicine, 8: 61-69.

Gull A, Kmalesh P and Kumar P (2015). Optimisation and functionality of millet supplemented pasta. Food Science and Technology, 35(4): 626-632.

Huffman SL and Martin LH (1994). First feedings: Optimal feeding of infant and toddlers. Nutr. Res., 14: 127-159.

International Food Research Journal, 23(1): 109-115.

Jain RK and Bal S (1997). Properties of pearl millet, Journal of Agricultural Engineering Research, 66: 85-91.

Joshi HC and Katoch KK (1990). Nutritive value of millets: A comparison with cereals and pseudocereals. Himalayan Res. Dev., 9: 26-28. 
Kamath MV and Belavady B (1980). Unavailable carbohydrates of commonly consumed Indian foods. J. Sci. Food Agric., 31: 194-202.

Karababa $E$ and Coskuner Y (2013). Physical properties of carob bean (Ceratonia siliqua L.): An industrial gum yielding crop. Industrial Crops and Products, 42: 440-446.

Krishnan R, Dharmaraj U, Sai Manohar R and Malleshi NG (2011). Quality characteristics of biscuits prepared from finger millet seed coat based composite flour. Food Chemistry, 129: 499-506.

Mariotti M, Alamprese C, Pagani MA and Lucisano M (2006). Effect of puffing on ultrastructure and physical characteristics of cereal grains and flours. Journal of Cereal Science, 43: 47-56.

Markowski M, Zuk-Gołaszewska K and Kwiatkowski D (2013). Influence of variety on selected physical and mechanical properties of wheat. Industrial Crops and Products, 47: 113-117.

McDonough CM, Rooney LW and Earp CA (1986). Structural Characteristics of Eleusine coracana (finger millet) using scanning electron and fluorescence microscopy. Food Microstructure, 5: 247-256.

Olapade AA, Babalola YO and Aworth OC (2014). Quality attributes of fufu (fermented cassava) flour supplemented with bambara flour. International Food Research Journal, 21(5): 2025-2032.

Pearson D (1981). The Chemical Analysis of Foods (8th ed.). Edingburg: Churchill Livingstone.

Raghuramulu N, Nair KM and Kalyansunduram S (1983). A manual of laboratory techniques. Hyderabad: National Institute of Nutrition; 1983. pp. 32-35.

Rao M, Muralikrishna G (2002). Evaluation of the Antioxidant Properties of Free and Bound Phenolic
Acids from Native and Malted Finger Millet (Ragi, Eleusine coracana Indaf- 15). J Agric Food Chem., 50: 889-892.

Sangamithra A, Swamy GJ, Sorna PR, Nandini K, Kannan K, Sasikala S and Suganya P (2016). Moisture dependent physical properties of maize kernels.

Shahidi F and Wanasundara PKJPD (1992). Phenolic antioxidants. Crit. Rev Food Sci Nutr., 32: 67-103.

Thompson LU (1993). Potential health benefits and problems associated with anti-nutrients. Food Res. Int., 26: 131-149.

Tiwari BK, Valdramidis VP, O'Donnell CP, Muthukumarappan K, Bourke $\mathrm{P}$ and Cullen PJ (2009). Application of natural antimicrobials for food preservation. J. Agric. Food Chem., 57: 59876000.

Varnamkhasti MG, Mobli $H$, Jafari A, Keyhani AR, Soltanabadi $\mathrm{MH}$, Rafiee $\mathrm{S}$ and Kheiralipour $\mathrm{K}$ (2008). Some physical properties of rough rice (Oryza sativa L.) grain. Journal of Cereal Science, 47: 496-501.

Venkateswaran V and Vijayalakshmi G (2010). Value addition to finger millet (Eleusine coracana) by germination and fermentation with Monascus purpureus. International Journal of food Science and Nutrition, 61(7): 722-727.

Xu W, Wei L, Qu W, Liang Z, Wang J, Peng X, Zhang $Y$ and Huang $K$ (2011). A novel antifungal peptide from foxtail millet Seeds. J Sci Food Agric., 91: 1630-1637.

Zewdu AD and Solomon WK (2007). Moisturedependent physical properties of tef seed. Biosystems Engineering, 96: 57-63. 